\title{
Elizabeth Warnock Fernea
}

\section{7-2008}

“BJ" FerNEA, writer, filmmaker and Professor Emerita of English, comparative literature, and Middle Eastern studies at the University of Texas at Austin, where she taught for twenty-four years, died after a two year illness on December 2, 2008 at the age of 81. A native of Milwaukee, Fernea grew up in the town of Flin Flon in Manitoba, Canada and in Portland, Oregon. She attended Reed College in Portland, like her spouse, Robert Fernea and her daughter, Laura Ann Fernea (Colorado), graduating in 1947. Fernea was at home in many places: a dusty street in Marrakech; a historic neighborhood in Cairo; the palace of the king and queen of Jordan; a film studio in London; at the opera in Houston, Texas; or dancing with Bob in a honky-tonk in Austin. Many years of her adult life were spent in the Middle East, and especially in the Arab world: Iraq, Egypt, and Morocco in particular. Wherever they settled, but especially at 3003 Bowman in Austin, BJ, along with Bob, created for friends and colleagues a welcoming, inclusive and creative space where people of an enormous range of backgrounds and divergent and conflicting perspectives could converse, a sort of on-going and moveable "salon" rare and precious in the world of academia, and for which she will be long-remembered by her students, friends and colleagues.

With a life-long delight in working collaboratively with people across cultures, professions, classes, ethnicities, ages and genders, Fernea first came to notice as an astute observer of cultural dynamics when she published in 1965 Guests of the Sheik, a work about the varied lives of Iraqi women in a small southern Iraqi town where she lived for almost two years from 1956 to 1958 . The book, which remains in publication over forty years later, was a forerunner among the reflexive ethnographies that began to appear in the 1960s and 1970s. (In fact, the book was enough ahead of its time as "ethnography" that it was not referred to as such until the 1968 edition). Her subsequent films and books, as well as her efforts to bring otherespecially Middle Eastern-writers and scholars to Western attention, continued to bring together a lively and diverse group of family, friends, and colleagues with multiple talents and interests, many centered around the Arab world. These included her husband Robert Fernea, Professor Emeritus of Anthropology and Middle Eastern Studies at the University of Texas at Austin, Basima Bezirgan, subsequently Middle East librarian at the University of Chicago, Annes McCann-Baker and Daniel Goodwin, who both edited the Middle East series at the University of Texas Middle East Center. numerous Middle Eastern scholars and writers, many of whom are featured 
in her edited works, filmmakers like Marilyn Gaunt, photo-journalists and art photographers working in the Middle East, Thomas Hartwell and Randa Shaath, the Moroccan author Leila Abouzeid, and her good friends and colleagues Caroline and John Williams. Her scholarly books include Middle Eastern Muslim Women Speak, Women and the Family in the Middle East, In Search of Islamic Feminism, and Remembering Childhood in the Middle East. She co-authored with Robert Fernea The Arab World: Personal Encounters and Nubian Ethnographies. In addition, she wrote two auto-ethnographies, A View of the Nile and A Street in Marrakech. A volume of essays, Fantasy or Ethnography: Irony and Collusion in Subaltern Representation was issued in her honor after her quarter as Distinguished Visiting Professor at The ohio State University in the early 1990s. She has had several books dedicated to her, including Romancing the Real, my own work, and is the recipient of numerous honors and awards, including NEH and Ford Foundation funding for some of her film work, which include Saints and Spirits, Veiled Revolution, The Price of Change, Women under Siege, The Struggle for Peace: Israelis and Palestinians, The Road to Peace: Israelis and Palestinians, and Living with the Past. She was chairwoman of the University of Texas' Women's Studies Program (which she helped found) from 1980 to 1983, before retiring in 1999. She was president of the Middle East Studies Association of North America from 1985-1986. Before her death she was working both on a series of short stories and on a cookbook that included recipes from those who influenced her cookery, from her mother and father, to her fellow college students (one of whom, a bear hunter, taught her to cook bear) and her Texas and Middle Eastern friends.

Professor Fernea is survived by her spouse, Robert Fernea, two daughters Laura Ann Fernea (Alberto Colorado) and Laila (Wes) Stroben, one son, David (Kim) and grandchildren Isabel, Maya and Adela Colorado, Emma, Bradley and Jack Stroben, and Weston and Ethan Fernea.

Sabra J. Webber Ohio State University 